\title{
EDUCATIONAL PRACTICE WITH WOMEN IN THE COMMUNITY: PREVENTION OF PREGNANCY IN ADOLESCENCE ${ }^{1}$
}

\author{
Joyce Mazza Nunes², Eliany Nazaré Oliveira3, Soleane Mazza Nunes Bezerra4, Patrícia Neyva Pinheiro da \\ Costa ${ }^{5}$, Neiva Francenely Cunha Vieira ${ }^{6}$
}

${ }^{1}$ Article extracted from the dissertation - Educational technology: a women's group's proposal for health promotion', presented to the Postgraduate Program in Nursing, Universidade Federal do Ceará (UFC) in 2010.

2 Doctoral student on the Postgraduate Program in Nursing, UFC. Family Health Strategy nurse in Fortaleza. Fortaleza, Ceará, Brazil. E-mail: joycemazza@hotmail.com

${ }^{3}$ Ph.D. in Nursing. Professor on the Undergraduate Nursing Course, Vale do Acaraú State University. Sobral, Ceará, Brazil. E-mail: elianyy@homail.com

${ }^{4}$ Social Worker. Undertaking M.A in Social Work, Work and Social Questions, Universidade Estadual do Ceará (UECE). Fortaleza, Ceará, Brazil. E-mail: soleanemazza@bol.com.com.br

${ }^{5}$ Ph.D. Adjunct Professor of the Department of Nursing and the Postgraduate Program in Nursing, UFC. Fortaleza, Ceará, Brazil. E-mail: neyva@ufc.br

${ }^{6}$ Ph.D. in Health Education. Full Professor of the Department of Nursing and the Postgraduate Program in Nursing, UFC. Researcher of the National Council for Scientific and Technological Development (CNPq). Fortaleza, Ceará, Brazil. E-mail: nvieira@ufc.br

\begin{abstract}
In educational practice in health, the subjects' knowledges and contexts are valued, supporting necessary changes. This study aims to report the experience of educational practices undertaken with 11 women of a community in Fortaleza, in the Brazilian state of Ceará, using Community-Based Participatory Research to investigate, identify and study the health problems which are important for that community. The participants showed that the prevention of pregnancy in adolescence was a priority in the community. Thus, the causes of this occurrence were reflected upon and analyzed, and actions which could reduce this were planned and undertaken. A film was made for adolescents, focusing on pregnancy in adolescence, demonstrating the dramas and difficulties experienced by the adolescents and their families. The study shows the potential which groups have for community mobilization and confrontation of the problems, as, when involved in the educational processes, they are able to provoke individual and collective changes, increase their autonomy and exercise their citizenship.
\end{abstract}

DESCRIPTORS: Health promotion. Health education. Women's health. Community participation.

\section{PRÁTICA EDUCATIVA COM MULHERES DA COMUNIDADE: PREVENÇÃO DA GRAVIDEZ NA ADOLESCÊNCIA}

RESUMO: Na prática educativa em saúde valorizam-se os saberes e realidades dos sujeitos, apoiando mudanças necessárias. Objetivase relatar a experiência de práticas educativas desenvolvidas junto a 11 mulheres de uma comunidade de Fortaleza-CE, utilizando a Community-Based Participatory Research, para investigar, identificar e estudar os problemas de saúde importantes para aquela comunidade. As participantes manifestaram ser prioritária a prevenção da gravidez na adolescência na comunidade. Assim, foram refletidas e analisadas as causas dessa ocorrência, planejaram-se e executaram-se ações que pudessem amenizá-la. Fez-se um filme para adolescentes, enfocando a gravidez precoce, demonstrando os dramas e dificuldades vivenciadas pelos adolescentes e suas famílias. O estudo demonstra o potencial que os grupos possuem para mobilização comunitária e enfrentamento de seus problemas, pois, quando envolvidos nos processos educativos, são capazes de provocar mudanças individuais e coletivas, aumentar sua autonomia e exercer sua cidadania.

DESCRITORES: Promoção da saúde. Educação em saúde. Saúde da mulher. Participação comunitária.

\section{PRÁCTICA EDUCATIVA CON MUJERES DE LA COMUNIDAD: PREVENCIÓN DEL EMBARAZO EN LA ADOLESCENCIA}

RESUMEN: En la educación en salud se valoran conocimientos y realidades de sujetos, con apoyo a cambios necesarios. El objetivo fue describir la experiencia de prácticas educativas desarrolladas con once mujeres de una comunidad de Fortaleza-CE, Brasil, utilizando la Community-Based Participatory Research, para investigar, identificar y estudiar problemas de salud importantes para la comunidad. Las participantes expresaron la prevención del embarazo en la adolescencia como prioridad. Por lo tanto, se reflejó y se analizaron las causas de este suceso, se planificaron y ejecutaron acciones que podrían aminorarla. Se produjo una película para adolescentes, centrándose en el embarazo temprano, para señalar tragedias y dificultades experimentadas por adolescentes y sus familias. El estudio demuestra el potencial de los grupos para movilización de la comunidad y enfrentamiento de sus problemas, pues cuando envueltos en los procesos educativos son capaces de inducir cambios individuales y colectivos y, se aumenta la independencia y ciudadanía.

DESCRIPTORES: Promoción de la salud. Educación en salud. Salud de la mujer. Participación comunitaria. 


\section{INTRODUCTION}

In health promotion, health education actions are potentially decisive interventions, as they are undertaken based in the problematization, analysis and propositions of the health professionals in the community, the subjects of the process. ${ }^{1}$ In this perspective, this practice takes on a new character, given that its guiding axis is that the strengthening of the subjects' ability to choose, assuming that the information regarding health is worked upon simply and in context, instrumentalizing the people to make healthier life choices. ${ }^{2}$

This being the case, it is essential to have done with the understanding of health education only as the passing-on of information from health professionals to service users; as a politicalpedagogical act, health education requires the development of reflection on the context as a historical and social subject which guides them to autonomy, emancipation, and to taking decisions for themselves, their families, and the collectivity. ${ }^{3}$

Health education must be a practice serving as a basis for, and reorienting, all of healthcare and not just be one more activity to be undertaken in the health services. ${ }^{4}$ It is a practice inherent to all the activities undertaken in the ambit of the Unified Health System (SUS, in Portuguese), allowing articulation between all the levels of management of the system, and is essential both for the shared formulation of health policies, and for the actions to happen with the service users' participation. ${ }^{5}$

In the Family Health Strategy (ESF, in Portuguese), the teams must be alert to health promotion concepts, developing strategies for health education which value the socio-cultural resources of the territorial area covered by their health center; working, furthermore, intersectorially and interdisciplinarily. ${ }^{6}$

In spite of the advances made in this area of work, many of the educational practices undertaken by health professionals, including nurses, still keep an educational-preventive focus, failing to incorporate the understanding of the social determinants of the health problems or - further - the needs and knowledges of the population assisted. ${ }^{7}$

In the light of the above, it should be noted that, although health education practice is not a recent proposal, at the present time it is a challenge, often remaining based in the biological model, which does not allow one to achieve the true ideal of health education, which is the autonomy and emancipation of those involved, promoting these subjects' empowerment to decide which actions are most appropriate in order to promote, maintain and recover their health.

Considering this challenge, this study raised the following questions: how should one undertake educational activities based in the participation and emancipation of the community in the ESF? How does the clientele respond to this action?

The responses to these questions may indicate methodological paths for strengthening health education practices in conjunction with the community, as, through viabilizing community educational activities and demonstrating what processes of this nature are produced with the subjects, one allows a different perspective regarding health education actions, in addition to contributing to the improvement of this practice in the ESF, especially the nurses' practice.

In this way, the study aims to report the experience of educational practice developed in conjunction with women from the community, focusing on their local contexts and needs, which culminated in the production of a film on pregnancy in adolescence.

\section{METHODS}

This is an experience report on educational practice undertaken in the ESF, which, intentionally, used Community-Based Participatory Research (CBPR), and a collaborative investigative approach, which involves equally all of the subjects in the process, and recognizes the strong points which each one brings. This begins with an issue of importance for the community, and aims to combine knowledge with action and achieve social change in order to improve the health results and reduce health inequalities. ${ }^{8}$ This being the case, the decisions are taken jointly between all the participants, who evaluate and reflect upon the problem and decide what to do in order to reduce or eliminate it.

The works of Kurt Lewin and Paulo Freire emphasize an interactive process of action, reflection and experiential learning, which is essentially the basis of CBPR. ${ }^{9}$ In CBPR, the study subjects are partners, participating actively in all the stages, from the planning through to the publicizing of the results obtained in the partnership. The first step in this approach is to identify the partners and to formalize and strengthen the partnership.

In this study, the partnership was established between four members of a Family Health Team (one nurse and three Community Health 
Workers - CHWs) and 11 young women (20 to 38 years old) living in a community in the outskirts* of Fortaleza in the Brazilian state of Ceará (CE) assisted by this team.

They participated in a group in the community, coordinated by the above-mentioned Family Health Team. The group met approximately 16 times, with one meeting per week, during the second semester of 2009. In the meetings, the discussions were guided by the stages of CBPR: 1) Investigate that community's problems; 2) Identify and define the priorities for the questions with which the partners will work; 3) Use the local knowledge for studying and understanding the health problems which are priority for the community; 4) Use the local knowledge for planning the necessary interventions; 5) Implement the planning elaborated by the partnership; and 6) Publicize the results obtained by the partnership.

The information gained from each meeting of the partnership was recorded, through the digital recording of dialogues, and a field diary. The transcripts of the recordings of the meetings were read and re-read, and the relevant questions were selected, which were emphasized as a form of results in the study. Participants' statements are presented below.

The study was approved by the Research Ethics Committee of the Federal University of Ceará (UFC), in accordance with protocol n. 153/09, following Resolution 196/96 of the National Health Council regarding research involving human beings. ${ }^{10}$ In order to preserve the anonymity of each woman who participated, the letter $P$ was used, followed by sequential numbers - such as, for example, P1, P2, P3 and so on successively until P11. They signed the terms of consent.

\section{REPORT OF THE EXPERIENCE}

In undertaking educational activities, it is essential to investigate participants' socio-cultural characteristics, such that this practice may be suited to the context. The 11 women were in an age range covering 20 to 38 years old. In relation to educational level, one was illiterate, five had not finished junior high school, and five had studied to senior high school level. Half of them were housewives and three worked in sales, while the remaining three were a student, a teacher and a seamstress. The majority of the women were in a stable relationship, with children. Their family income was up to three minimum salaries.

The first stage of CBPR is to identify the partners and formalize the partnership. This was the initial period, when the women were invited by the CHWs to participate in the study. Thus, the first three meetings were dedicated to strengthening the partnership, through presenting the participants, their expectations, doubts and motivations - as well as the aim of the study, presented by the team responsible. For this, educational strategies and game activities were undertaken. The place, time and frequency of the meetings were agreed.

CBPR starts with an issue of importance for the community, and has the objective of combining knowledge with action so as to achieve a social change for improving the health results and eliminating health inequalities. As a result, it is necessary to define priorities. ${ }^{9}$

In the meetings with the participants, issues such as breast cancer, infertility and pregnancy in adolescence were mentioned as relevant for that community. It was necessary, however, to select one theme as a priority for discussion and deepening, which should also be relevant for other women from the community. This stage took place during two meetings.

\section{Pregnancy in adolescence}

The subjects were unanimous in selecting pregnancy in adolescence as a priority, as three women who already had adolescent children thought it important to learn more about the subject, in order to help them with educating their children; others had become mothers while adolescents themselves and experienced this situation. They reported that in the community, pregnancy in adolescence was common, and that as a result it was a priority to work in preventing it.

In the third period, during four meetings, the participants' knowledge was used in order to analyze, reflect upon and understand pregnancy in adolescence in that community. The discussions involve the participation of other health professionals working in the Family Health Center (FHC), who were the dentist, nutritionist and physical education specialist, as well as undergraduate students in the health area.

\footnotetext{
* The outskirts of Brazilian cities are broadly equivalent to poor inner city areas in the United States. Social and housing conditions tend to be worse than in developed countries, however. Translator's note.
} 
The women spoke among themselves, expressed opinions, shared experiences and deepened the discussion, bringing it to their own contexts, to the concrete, to their surroundings, in the family and in school. They reported their experiences in the cases of pregnant adolescents, and families whom they knew in the neighborhood; thus, the conversation flowed naturally, with the increasingly active participation of the women, who expressed their ideas and emphasized the responsibilities which applied to the parents and the children. I think that conversation influences things a lot, because I talk with and teach mine, I give them the examples of friends of theirs, of the family, for them to see which is the right path and which the wrong (P11); I talk with my children, I say that when he is going to get up to something like that, he is to use a condom, and not to bring babies home to me (P5).

One participant reported her experience with pregnancy in adolescence: I was 13 years old, I don't know, I was so young and I didn't know anything. To me, I wasn't bothered what I did. I didn't study, only up until I was ten years old, and I separated from my partner when I was 18 years old (P5).

The women believe that pregnancy in adolescence must be discussed with boys and girls, who have equal obligations. They report that in that community the adolescents are idle and have no plans for their lives, which also contributes to the occurrence of pregnancy in adolescence. I think it is lack of prospects in life, not having anything to do, not having a dream to follow, that causes this thinking about having a child for the rest of your life, that's all it can be (P6); I think that if the adolescents had more to occupy their minds, it wouldn't put an end to the pregnancies, but it would reduce them. For example, encouraging things which adolescents like to do, like sport (P7).

The participants discussed and reflected upon pregnancy and adolescence in the community, attempting to understand the factors which promote this occurrence. In the women's opinion, the adolescents in that neighborhood have restricted leisure options, few prospects in life and little information on methods of contraception, which promotes the occurrence of unplanned pregnancy. A neighborhood like this has nothing to do, so they hang out on street corners, thinking about and getting up to no good, there really is nothing to do... The adolescents need somebody to encourage them, they don't have any ideas, because the ideas which they have are just to do with dating and doing stuff they shouldn't (P8).

The group understands that pregnancy in adolescence is a complex question, which requires strategies from various sectors of civil society. In the fourth stage of the CBPR, the participants thought about strategies which could contribute to reducing adolescent pregnancy in that community. I think that we have some ideas for involving the adolescents here... (P3); How are we going to make them listen to us? If there is school and they don't go to it, if they don't even know us, how are we going to get to them? It would have to be in the community, as many don't go to school (P4); We could set up an adolescents' group, there in the building, similar to what we do here, but with more dynamics, more games, to call their attention (P6).

In two meetings, after discussing the situation of adolescent pregnancy in that neighborhood, they identified the strong points and arrived at a consensus regarding what should be done to reduce the occurrence of adolescent pregnancy in that community, and planned activities whose undertaking was viable. It was decided to make a film, based in the local context, to be shown to the adolescents at an event in the neighborhood, as a means of showing pregnancy in adolescence, and the difficulties experienced.

\section{The film}

The fifth period of the CBPR corresponds to the interventions planned by the participants. In the three meetings, the group planned the production of a film for the adolescent public on adolescent pregnancy, titled "Girl Mother". The film, elaborated by the participants, told the story of an adolescent girl who became pregnant by her boyfriend who did not take any responsibility for the child.

Six women from the group, voluntarily, wrote the script and the storyline of the film and provided the costumes and the place for filming, in the house of one of them. They played the role of the pregnant adolescent, the adolescent father, the family, and other adolescent friends. The nurse who participated did the filming and edited the film. The women were concerned that the film should be shot in accordance with local context, and therefore used songs which were known in the community, as well as language and slang characteristic of the adolescents in the neighborhood, as well as clothes.

The film addressed the adolescent's relationship with her mother, the influence of her friends, and the casual dating, as well as unprotected sexual relations. It also included voluntary state- 
ments from the women who had become mothers in adolescence themselves.

Following the editing of the film, the six participants in the filming were the first to watch it, with the aim of suggesting necessary changes, should there be any, which did not happen. Following that, the film was presented to the other women who participated in the study - but not the film - so that they could also contribute their opinions in relation to it. This fact occurred so that the participants in the study could validate the content of the collective production.

The film "Girl Mother" was later shown to the adolescents of the neighborhood, in an event promoted by the group of women themselves, with the aim of raising awareness about the importance of preventing pregnancy. The women publicized this event in the community, distributing invitations to the adolescents in their homes and/or in places in the neighborhood where there was a large flow of persons, such as in the shops, among others.

As a result, the community's I Meeting of Adolescents took place, undertaken in the morning and afternoon periods in the same place as the women's group's meetings. Approximately 150 adolescents attended and assisted the film produced; following which, they participated in a discussion about the drama, led by the women's group and health professionals. During the showing of the video, the adolescents played close attention to the plot, which emphasized the problem of pregnancy in adolescence. As this was a film made in the community itself, whose "actresses" were women who lived there, using speech characteristic of the region, the film was well-accepted by the adolescents, who enjoyed the storyline and were able to visualize that situation of pregnancy in adolescence.

They also participated in conversation circles, workshops, group dynamics and educational games, with the aim of providing guidance in the use of methods of contraception and discussing the prevention of pregnancy in adolescence. The women themselves were responsible for leading the activities undertaken that day, supported by the health professionals. Vaccinations and health guidance were also offered that day.

All the participants made an effort such that the meeting with the adolescence should be successful. The adolescents who attended were welcomed by the group. The women showed satisfaction in being able to provide the adolescents of the neighborhood with a different day, with lots of energy, and also to contribute to the prevention of pregnancy in adolescence.

These women reported that they felt important in making a film which would contribute to the prevention of pregnancy in adolescence, as they could feel this context from close up. It was a great satisfaction, as we were able to bring together the adolescents to see the film, which dealt with our reality, and the problem our community faces (P4); It was very good, I had a lot of fun. It was very important, not just for me, but for the whole community. I discovered that when you have willpower and attitude, we can do incredible things, like the film (P8).

They reported the importance of the contact with other people from their own neighborhood, given the fact that some had never had the opportunity to help their community. They also showed satisfaction in being able to share their knowledge with the group: I felt very good, as I had never had this space, nor contact with my own community, and it was marvelous (P10); I felt that I was a useful person for the community, seeing the adolescents asking the questions, and me knowing how to answer and help them was marvelous! (P7); I felt like another person, helping the adolescents was great, because I had the opportunity to pass on something that I had learnt here in the group (P2).

In CBPR, once the partnership is functioning, the project is implemented, and the partnership must publicize the results obtained. ${ }^{9}$ The film also was presented by the participants to adolescents from a state school in the neighborhood; and to health professionals from the local FHC, as well as to other professionals who were participating in the course in the area of women's health, both at the request of the local management.

\section{REFLECTIONS ON THE EXPERIENCE}

The health problems of the community in question were always visible to those who lived in the neighborhood. It seemed, therefore, that they had become banal for the community: or that the community would not mobilize in order to change that context. The study made this awakening possible, contributing to the subjects' directing their attention to the context, focusing on the principal health problems and discussing these questions together, visualizing the possible options for confronting them, in a broad idea of health, identifying individual and collective responsibilities. This was the big differential of the educational practice undertaken in this study. 
One of the priority strategies in health promotion is making it possible for people to organize their own care for their health, based in their life experiences. ${ }^{11}$ This entails developing educational actions for subjects to acquire skills in the search for a healthy life, it being necessary for the subjects in the groups to seek to identify their objectives, meet their needs and thus contribute to the favorable change of their environment. ${ }^{11}$

The women's group directed its attention to a question which was a priority for the community adolescent pregnancy - and felt challenged by this problem, which is complex and involves various factors. They refused to lose heart, however, and united their strength to study the causes of pregnancy in adolescence in their neighborhood and to plan viable strategies for mitigating the situation.

For the women, this was not as difficult as it could have been, as they knew both the context and the people. Furthermore, some of them had already experienced pregnancy in adolescence, and therefore had a profound understanding of this experience. It is therefore reconfirmed that Health Promotion actions must take into account the subjects' experiences in the way that each one faces her needs; and how, together as a community, they exercise their citizenship and are able to produce transformations in their context. ${ }^{12}$

The discussions in the group meetings, in which the women shared experiences and reflected on their context and its strong points, and planned strategies for attempting to mitigate the problem, contributed to increasing the autonomy and emancipation of the women involved, empowering them, as this interaction facilitates the forming of opinions and attitudes as they become more willing to dialogue and share experiences. ${ }^{13}$

In one study undertaken with a group of pregnant women, there was also frequent exchanging of experiences and the sharing of ideas, contributing to achieving knowledge and group experience, culminating in the transformation of the individual and collective context. ${ }^{14}$ With one group of mothers caring for children in hospital, the exchanging of experiences between the participants represented a form of collective empowerment. ${ }^{15}$

Supported by the health professionals involved, who contributed to the group discussions by adding health knowledge, assisting the undertaking of the activities planned and in overcoming difficulties, the women made every effort to produce a film based in their context and to undertake the meeting with the adolescents, aiming to prevent pregnancy in adolescence.

This also demonstrates the protagonism and the empowerment of women from a community who, facing its local problem, refused to twiddle their thumbs and watch: they discussed their problems and tried to mitigate them, with support and encouragement from the health team, and thus exercised their citizenship. The subjects' protagonism allowed the strengthening of their autonomy, assisting them in making decisions which affect their lives. ${ }^{13}$

A subject is empowered when she has freedom to take her own decisions, being supplied with the necessary information for this. ${ }^{15}$ As a result, it is believed that the empowerment of the women who were partners in this study was acquired during each stage, when they chose a priority question for the community, investigated and studied the causes of adolescent pregnancy in that neighborhood, decided what should be done to reduce it, and implemented the plan. Jointly, as a group, they were able to take the decisions for changing the context of the neighborhood, based in their previous knowledge and that obtained through the sharing of experiences between the participants.

In one experience involving a theatrical production in which adolescents participated in a production with themes based on the social and family experiences, it was observed that this was a valid strategy, resulting in the mobilization and empowerment of the subjects and the local community, for the promotion of health. ${ }^{16}$

These events prove that the clientele of the health services is potentially capable of promoting health actions, through its various possibilities and encouragement from health professionals. ${ }^{16}$ In education for the population, it is important that - through dialogue - one can "challenge the groups of the population so that they perceive, in critical terms, the violence and profound injustice which characterize their concrete situation". 17:48

The learning constituted by the partnership, for the women, not only promoted the recognition of the context, but also enabled them to contribute to the transformation of the context, being subjects of their history. They felt important in helping their community to overcome its problems, as they had never had this opportunity, and participation in the group made this community work possible.

This study makes clear that the community needs to be supported in order to use its 
strengths to resolve its social problems. Often, a little goodwill and willingness to help from health professionals is enough to help the members of the community to get past the initial difficulties.

\section{FINAL CONSIDERATIONS}

This experience with the community partnership allowed significant learning in health promotion/health education and brought attention to the potential which the groups have for community mobilization and confrontation of the problems. It also made it possible to see how the work of the ESF with adolescents should be a priority - especially in health education practice - and that the issue of pregnancy in adolescence is still shown to be frequent and also relevant at the present time, despite being heavily studied.

Health promotion presupposes the recovery of community participation, which must be encouraged, recognizing people as able to promote their care. In this perspective, it is important to encourage the forming of groups in the community assisted by the ESF, as - besides contributing to the promotion of these subjects' health - these can become partners in confronting their community's principal problems.

In health education practice in the ESF, it is necessary to innovate and to recover the social spaces existing in the neighborhood, to create support networks for the community and to act interdisciplinarily. For this, it is necessary to go beyond the physical limits of the FHC and go into the territory and get to know the community, the families and the subjects, as well as their needs and strengths.

In the ESF, the nurse is a professional who has every possibility for this recognition, as she is very close to the families and community. Her practice must include community participation, with respect for their culture, valuing the real local needs, and contributing to increasing the subjects' autonomy, community empowerment, social change and transformation of the subjects into true protagonists of their lives.

Ultimately, this study's initial questions were answered, confirming that it is indeed possible to undertake educational activities from a perspective based in the participation and emancipation of the community in the ESF, through a community partnership based in the local context and needs. The subjects, when motivated and supported, respond positively to processes such as these.
It is believed that the experience presented through the community partnership will contribute to a renewed vision of educational practice in the ESF, with a view to promotion of community and individual health, valuing the population's knowledge and the community's participation in health decisions, sensitive to the real needs of the subjects in the community and contributing to social change, as the study shows that this work can be undertaken by the nurse working in the ESF.

The results found in this study were possible thanks to the involvement of the health professionals and the active participation of the subjects, as they are directly related to the fact that it was undertaken with a group of women in the $\mathrm{ESF}$, using the CBPR approach. It is not known, therefore, how other groups, such as adolescents or older adults, among others, respond to processes such as these; for this, it is necessary to undertake further studies.

In this perspective, for this strategy to be effective in similar situations, it is advised that it needs to be constituted collectively, taking into account the local culture, knowledges, context and needs.

\section{REFERENCES}

1. Cervera DPP, Parreira BDM, Goulart BF. Educação em saúde: percepção dos enfermeiros da atenção básica em Uberaba (MG). Ciênc Saúde Coletiva [online]. 2011; [acesso 2013 Ago 24]; 16(1): Disponível em: http:/ / www.scielo.br/pdf/csc/ v16s1/a90v16s1.pdf

2. Alves GG, Aerts D. As práticas educativas em saúde e a Estratégia Saúde da Família. Ciência Saúde Coletiva [online]. 2011 [acesso 2013 Ago 24]; 16(1): Disponível em: http://www.scielo.br/pdf/csc/ v16n1/v16n1a34.pdf

3. Machado MFAS, Monteiro EMLM, Queiroz DT, Vieira NFC, Barroso MGT. Integralidade, formação de saúde, educação em saúde e as propostas do SUS - uma revisão conceitual. Ciênc Saúde Coletiva. 2007 Mar-Abr; 12(2):335-42.

4. Leonello VM, Oliveira MAC. Competencies for educational activities in nursing. Rev Latino-Am Enferm. 2008 Mar-Abr; 16(2):177-83.

5. Ministério da Saúde (BR). Secretaria de Gestão Estratégica e Participativa. Departamento de Apoio à Gestão Participativa. Caderno de Educação Popular e Saúde. Brasília (DF): MS; 2007.

6. Alves LHS, Boehs AE, Heidemann ITSB. A percepção dos profissionais e usuários da Estratégia de Saúde da Família sobre os grupos de promoção da saúde. Texto Contexto Enferm. 2012 Abr-Jun; 21(2):401-8. 
7. Acioli SA. A prática educativa como expressão do cuidado em saúde pública. Rev Bras Enferm. 2008 Jan-Fev; 61(1):117-21.

8. Minkler M, Wallerstein N. Community-based participatory research for health: from process to outcomes. São Francisco (US): Jossey-Bass; 2008.

9. Faridi Z, Runbaum JA, Sajor Gray B, Franks A, Simoes E. Community-based participatory research: necessary next steps preventing chronic disease. Prev Chronic Dis [online]. 2007 [acesso 2008 Dez 06]; 4(3). Disponível em: http:/ / www.cdc.gov/pcd/ issues/2007/jul/06_0182.htm

10. Ministério da Saúde (BR). Conselho Nacional de Saúde, Comissão Nacional de Ética em Pesquisa. Resolução n. 196 de 10 de outubro de 1996: diretrizes e normas regulamentadoras de pesquisa envolvendo seres humanos. Brasília (DF): MS; 1996.

11. Cunha RR, Pereira LS, Gonçalves ASR, Santos EKA, Radünz V, Heidemann ITSB. Promoção da saúde no contexto paroara: possibilidades de cuidado de enfermagem. Texto Contexto Enferm. 2009 Jan-Mar; 18(1):170-6.

12. Oliveira SHS, Monteiro MAA, Lopes MSV, Brito
DMS, Vieira NFC, Barroso MGT, Ximenes LB. Estratégias de enfrentamento da pobreza e sua interface com a promoção da saúde. Rev Latino-am Enfermagem. 2007 Set-Out; 15(esp):867-73.

13. Trindade WR, Ferreira MA. Grupo feminino de cuidado: estratégia de pesquisa-cuidado à mulher. Rev Bras Enferm. 2009 Mai-Jun; 62(3):374-80.

14. Hoga LAK, Reberte LM. Action-research as a strategy to develop pregnant women group: the participants' perception. Rev Esc Enferm USP [online]. 2007 [acesso 2013 Ago 20]; 41(4). Disponível em: http://www.scielo.br/pdf/reeusp/v41n4/03.pdf

15. Neves ET, Cabral IE. Empoderamento da mulher cuidadora de crianças com necessidades especiais de saúde. Texto Contexto Enferm. 2008 Jul-Set; 17(3):552-60.

16. Harada MJCS, Pedroso GC, Pereira SR. O teatro como estratégia para a construção da paz. Acta Paul Enferm. 2010 Maio-Jun; 23(3):429-32.

17. Freire P. Pedagogia da autonomia: saberes necessários à prática educativa. São Paulo (SP): Paz e Terra; 1996. 